\title{
PIERRE MERLIN: L'AMÉNAGEMENT DU TERRITOIRE EN FRANCE
}

\author{
(La documentation Française, Paris, 2007. 174 o.)
}

\section{EGYED ILDIKÓ}

Franciaországban a területfejlesztési politika (aménagement du territoire) a nemzeti erőforrások kiegyenlítettebb elosztásának igényéböl született a második világháborút követően. Fél évszázados történetét áttekintve érdemes mérleget vonni az egymást követő politikák sikeréröl. Milyen gazdasági és társadalmi folyamatok hatására fordul szembe a területfejlesztés eredeti céljával és válik a gazdaságfejlesztés és a hatékonyság szolgálatába állított politikává? A kezdetben területi harmonizáció jegyében zajló területfejlesztés irányítási szerve - a DATAR (Délégation à l'Aménagement du Territoire et à l'Action Régionale) - miért és hogyan müködik 2006-tól kezdve, mint DIACT (Délégation Interministérielle à l'Aménagement et à la Compétitivité des Territoires), nevében foglalva a területi versenyképesség erősítésének célkitüzését. Milyen gyökerei vannak a területfejlesztésnek Franciaországban és a szerző által „úttörönek" tekintett országaiban (Hollandia, a volt Szovjetunió és Nagy-Britannia)? Mikor és hogyan vált a területfejlesztés a nemzeti politikák fó tengelyévé? Vannak-e vitathatatlan eredmények, beszélhetünk-e jelentős fejlődésről? Milyen területi szinteken valósul meg, milyen tartalommal?

Melyek a területfejlesztés fö mozgósítható eszközei, az adminisztratív struktúrák, pénzügyi és fiskális mechanizmusok? Hogyan egyeztethetö össze a gazdasági tervezés, a területi tervezés (területfejlesztés) és a decentralizált hivatali müködés? Vajon az Európai Unió és a globalizáció kihívásai alapjaiban rendítették-e meg a területfejlesztés létjogosultságát és feltételeit? Beszélhetünk-e egyáltalán francia nemzeti területfejlesztési stratégiáról a gazdasági globalizáció és liberalizmus kontextusában? Vajon a területfejlesztés nem áll-e szöges ellentétben az Európai Unió és a gazdasági globalizáció hatékonyságot és versenyképességet ösztönző céljaival? Melyek a francia gazdaság gyenge pontjai és milyen követendő irány kínálkozhat a területfejlesztés számára a 21. században?

Ezekre a kérdésekre keresi a választ Pierre Merlin 2007-ben megjelent könyvében. A szerző, a területfejlesztés jeles szakértője, a Paris I Panthéon Sorbonne Egyetem professor emeritusa, a Sorbonne Urbanisztikai és Területfejlesztési Intézetének elnöke. Az urbanisztika, területfejlesztés, közlekedés, demográfia, turizmus témaköreiben megjelent, sokat hivatkozott publikációinak száma meghaladja a félszázat.

A könyv kilenc jól elkülöníthetö, de egymásra épülö fejezetre tagolódik. Az első fejezetben a szerző bemutatja a területfejlesztés eredetét, francia és külföldi példákkal illusztrálva, majd elemzi a második világháborút követő időszakban kibontakozó, 
Tér és Társadalom 22. évf. 2008/4. 229-243. p.

átfogó francia területfejlesztési gyakorlat kezdeteit. A szerző rámutat arra, hogy a területfejlesztés fogalma viszonylag későn, a második világháborút követően születik. Pierre Merlin a fogalmat sokoldalúan értelmezi és a lehetö legpontosabban definiálja. Definiciója szerint: A területfejlesztés az emberek és tevékenységeik, az általuk használt létesítmények és kommunikációs eszközök nemzeti térben - valamilyen rendező elv szerint - való elhelyezésének jövőorientált akciója és gyakorlata (inkább, mintsem tudománya, technikája vagy pedig müvészete), amely figyelembe veszi a természeti, emberi és gazdasági (stratégiai) korlátokat, mindezt abból a célból, hogy az emberek közötti funkciók és kapcsolatok a lehetö legkényelmesebb, leggazdaságosabb és legharmonikusabb módon valósuljanak meg (11.o.).

A fogalmi tisztázást követően a szerző a területfejlesztés jellegét tárgyaló tudományos viták eredményeit összegzi. Arra a következtetésre jut, hogy a területfejlesztés sem a tudományok, sem a müvészetek, sem a technikák körébe nem sorolható, ehelyett inkább empirikus alapokra támaszkodó gyakorlatnak és tevékenységek összességének (praxisnak) célszerủ tekinteni. A területfejlesztést kisajátítani szándékozó, egymással rivalizáló tudományágazatok (földrajz, építészet, műszaki tudományok) divergáló céljai közötti konszenzus szükségességére hívja fel a figyelmet a szerző, ennek hiányában ugyanis a hatékonyság rovására történő szétaprózódás fenyegeti a célok megvalósulását.

A második fejezetben a szerző a területfejlesztési politika megvalósulásának szintjeit (európai kontinens, régiók, helyi szint) elemzi, majd áttekinti a nemzetközi együttmüködések eredményeit. Franciaországban a helyi szint, amelyet a közösségek nagyfokú szétaprózottsága (36784 község) jellemez, ideális esetben tovább bontható földrajzi, gazdasági, szociális és kulturális egységet képviselő interkommunális szintre, amelyet a valóságban gyakran helyi politikai érdekek határoznak meg. Az interkommunális szint a területhasználat irányainak a meghatározásában játszik jelentős szerepet, a célokat a területi koherencia tervekben (SCOT schéma de cohérence territoriale) rögzítik. A helyi szint következö eleme a község, majd a városnegyed következik: itt valósulnak meg a konkrét müveletek, itt zajlanak a beruházások, az építkezések, a felújítások (az ötvenes évektől a hetvenes évek közepéig tartó nagy lakótelep építések), a történelmi városrészek rekonstrukciója és a lepusztult városnegyedek rehabilitációja, ezekben alakítják ki az összehangolt fejlesztési övezeteket (zone d'aménagement concerté).

A harmadik fejezetben a szerző sorra veszi a területfejlesztés eszköztárát, az Európai Unió növekvő befolyását, az irányító struktúrákat és à DATAR tevékenységét. A pénzügyi és fiskális ösztönzők (pénzügyi segélyek, az uniós és állami támogatások, kedvezményes kölcsönök, teljes vagy részleges adómentesség) bemutatása után sor kerül a központi tervezés-decentralizáció dilemmáját áthidaló tervszerződések rendszerének (régió-állam, vidék-állam, bizonyos városok és az állam, agglomerációk és az állam szerződései) bemutatására.

Külön alfejezet foglalkozik a területfejlesztési politika bizonytalanságaival 2007-ben, amelyek nagyrészt abból fakadnak, hogy a területfejlesztés nem tud egyértelmü választ adni a dilemmákra (gazdasági fejlödés vagy területi kiegyenlítódés, liberalizmus 
Tér és Társadalom 22. évf. 2008/4. 229-243. p.

vagy központi tervezés, hatékonyság vagy méltányosság, fejlesztés vagy környezetvédelem, centralizáció vagy decentralizáció). A kezdeti célok, amelyek a területi kiegyenlítődés, a központi tervezés, a területfejlesztés mellett tették le a voksot, mára megkérdőjeleződtek. Az Unió abszolút prioritásként a gazdasági fejlődést, a liberalizmust, a hatékonyságot, a gazdaság szolgálatába állított területfejlesztést és a döntési decentralizációt helyezi központba. Felmerül a kérdés, hogy létezhet-e még valódi francia nemzeti területfejlesztési politika ebben az összefüggésben? A szerző egyértelmủ válaszokat ugyan nem fogalmaz meg, de nézetei sejthetök.

A negyedik fejezet a központi területfejlesztési politika föbb állomásait elemzi. Az 1962 és 1975 között egymást követő nagy projektek formájában megvalósuló tervekkel az állam olyan növekedési pólusok megteremtését tüzte ki célul, amelyek Párizs ellenpontjaiként képesek mérsékelni a „Párizs és a francia sivatag” között tátongó fejlettségbeli szakadékot. Mérleget állítva a párizsi ipar 1955-75 közötti decentralizációjának politikájáról (2745 decentralizációs müvelet, 429489 új munkahely, 3200 vállalkozás) a szerző azt állítja, hogy ezek sehol sem feleltek meg a területfejlesztés céljainak, hiszen a munkahelyek több mint fele Párizs környékén létesült. A munkahelyeknek csupán negyede jött létre a kiemelt déli és délnyugati régiókban, az ipari szerkezetátalakítási gondokkal küzdő régiókban pedig mindössze $8 \%$-a. Pozitív eredmény, hogy néhány, korábban Párizs környékén koncentrálódó ágazat (autógyártás, repülőgépgyártás, gyógyszeripar, elektronika) decentralizációja megvalósult.

E nagyszabású infrastrukturális beruházásokkal, funkció- és munkaerő átcsoportosítással jellemezhető ipari decentralizációs politika az 1970-es évek közepén megtorpant. Az olajválság után az országban általános jelenséggé vált az ipari foglalkoztatottság hanyatlása és a munkahelyek megszủnése. A válságban lévő ágazatok megsokasodtak, tömegessé vált a munkahelyek bezárása, a vállalat-felszámolások napi gyakorlattá váltak. Ezeket a folyamatokat a globalizáció, valamint az értékteremtés mítosza általánossá tette és felgyorsította. Ưj prioritások születtek: meghatározták az ipari szerkezetátalakítási övezetek és pólusok lehatárolásának kritériumait. Legelőször a depressziós bányászati (Nord-Pas-de Calais, Lorraine, Midi, Loire, Ardennes) térségeket jelölték ki. A korszak legfontosabb intézkedése a 14 ipari rekonverziós zóna kijelölése volt 1984-ben. A volt nehézipari térségekből alakult zónák hivatalosan 2001-ben szüntek meg, de a gyakorlatban már sokkal hamarabb kikerültek a területfejlesztési politikák prioritásai közül, majd feledésbe merülttek. A fiskális, pénzügyi megoldások enyhítő hatásainál tartósabb megoldást eredményeztek e térségekben az aktív népesség új generációjának képzése, valamint a helyi adottságokra épülő fejlesztések (ủj tevékenységek meghonosodása, helyi jellegzetességek felértékelése, kezdeményezések támogatása).

A technológiai fejlesztés és kutatás programozásáról szóló 1982. évi törvény a régiók hatáskörébe helyezte a regionális innovációs és technológiai transzfer centrumok (CRITT) létrehozását. A nyolcvanas évek az innovációt és kutatást fókuszba helyezó politika és a technopoliszok szisztematikus fejlesztésének az időszaka (középvárosok sora fogalmazott meg technopoliszra alapozott fejlesztési stratégiát). A technológiai transzfert lehetóvé tevó, innovatív tevékenységeket magukban foglaló, 
Tér és Társadalom 22. évf. 2008/4. 229-243. p.

egyetemek és kutatóközpontok térbeli közelségéből profitáló technológiai parkok gyakorta helyi közösségek vagy ipari és kereskedelmi kamarák kezdeményezéseként alakultak meg, az állami szerepvállalás igen csekély mértékủ volt. Az alapvetố gondot ,az innováció regionális szintủ diffúziójának mítosza” okozza: kevés vállalkozás tart fenn szoros kapcsolatot az egyetemekkel vagy kutatóközpontokkal. A mérleg azonban 175 ezer munkahelyet és 7500 vállalkozást mutat. (Ehhez 50 tudományos parkban lévő 80 ezer munkahely és 3000 vállalkozás, valamint a 20 technológiai parkban 50 ezer munkahely és 2000 vállalkozás járul).

Az ötödik fejezet részletesen tárgyalja a hatvanas években uralkodó szemléletet, amely a nyolc metropolisz - Párizs ellenpólusai - fejlesztésétől remélte a fôváros hegemóniájának mérséklését. A cél a 20 . század végére a főbb agglomerációk népességének megkétszereződése, illetve megháromszorozódása volt. E politika irrealitása mára már igazolódott, hiszen akkor, a maival ellentétben magas volt a születések száma (egy nőre átlagosan három gyermek jutott), s a demográfiai növekedés üteme miatt a nagyvárosok felé áramló vándorlás erôteljes volt. Az, hogy a nemzetközi versenyben a nyolc nagyváros (métropole d'équilibre) fejlödése elmaradt a várt ütemtól, demográfiai növekedésük középvárosokénál is alacsonyabb üteme mutatja. A nemzetközi városversenyben csupán Lyon, Marseille és Lille érte el a kritikus tömeget ahhoz, hogy (szerény módon) felvehesse a versenyt más európai metropoliszokkal. A metropoliszok specializációjára nem került sor, $\mathrm{s}$ a regionális felosztást (22 régió) sem igazították a kiemelt nagyvárosok számához és fejlesztéspolitikájához. A fóvárosból a DATAR által irányított autoriter politika célkitüzései pedig nem vették figyelembe a helyi gazdasági miliöt és a helyi politika érdekeit.

A hetvenes években a területfejlesztési politika fókuszába a 20-100 ezer fős középvárosok kerültek. E várostípussal szemben olyan követelmények fogalmazódtak meg, mint a vidéki foglalkoztatottak megtartása és fogadása, a nagyvárosokénál kedvezőbb életfeltételek biztosítása, valamint a nagyvárosokból érkező fejlődési impulzusok térségük felé való közvetítése. Az intézkedések a középvárosok szük körét érintették, e politikára nagy költségeket nem fordítottak (csupán néhány száz millió frankot). 1983-ban, a decentralizációs törvények évében ez a politika is feledésbe merült. A helyi közösségek pénzügyi autonómiája ugyanis feltételezte, hogy a projektek megvalósítása a városok hatáskörébe kerüljön. Következtetésként a szerző úgy találja, hogy a középvárosok fejlesztése - hasonlóan tíz évvel korábban a metropoliszokéhoz - a DATAR fö prioritásai közé került, megszabva a területfejlesztési politika fó irányát, majd ugyanilyen hirtelen feledésbe merült.

A decentralizáció és regionalizmus által fémjelzett nyolcvanas években a városhálózatok fejlesztése került az állami területfejlesztési politikák középpontjába, külföldi példákból merítve az inspirációt (Baden-Würtenberg, Randstad Holland, Emilia-Romagna). Két típusuk jött létre: a középvárosok hálózata, amelyek elhelyezkedésük, helyi potenciáljaik és együttműködési készségük függvényében szerveződtek; valamint az egy nagyváros köré csoportosuló szervezödések (Lille, Lyon, Toulouse, Strasbourg) és azok befolyása alá tartozó városok, amelyek a maguk számára elönyöket kovácsolhatnak a fejlődési lehetőségekböl. A városhálózatok 
Tér és Társadalom 22. évf. 2008/4. 229-243. p.

dinamikáját azonban nagymértékben gátolja, hogy a társuló városok egymással rivalizálnak, és ha a DATAR ösztönzésére hajlandóak is társulni, ez mindenekelött az állam pénzügyi közremúködéséböl való részesedés reményében történik. A pénzügyi autonómia garantálásával az állami területfejlesztési politikát fenyegette a „kétsebességes" regionális fejlődés veszélye: a jelentős erőforrásokkal rendelkező, nemzetközi versenypozíciókért is harcoló fejlett ipari régiók (Île-de-France, RhôneAlpes, Provence Alpes-Côte d'Azur), a rurális régiók (Limousin, Auvergne) és az öneröböl való megújulásra képtelen, alacsonyan fejlett ipari régiók (Nord Pas-deCalais, Lorraine) között mélyülő szakadék.

A szerző röviden kitér a francia gazdaság problémáit (technológiai innovációs hátrány, francia termékek skálájának szükülése, a csúcsiparágakban való lemaradás) orvosolandó, 2005-ben megfogalmazott nagy célokkal kecsegtetö versenyképességi pólus programra. Itt már nem a DATAR kezdetek óta gyakorolt defenzív "tüzoltóo" politikáiról van szó, hanem egy olyan offenzív politikáról, amely „célul olyan valódi technológiai-gazdasági programok konstruálását túzte ki, amelyek az ipari, kutatási és a felsőoktatási szfërák közötti szinergiákra épülnek." A pólusok specializációja a siker alapvető feltétele.

Bár korai még mérleget vonni a közelmúltban indított programról, a problémák közül a szerző néhányat megemlít. A pólusok túlzottan nagy száma (67) mellett az egyetemek és a kutatói szfëra kapcsolata sok esetben csak szimbolikus jelentőségü, a kijelölt ágazatok nem mindig azok, ahol az innováció a legsürgetỏbb, illetve a legelőrehaladottabb; a pólusok specializációja nem mindenhol egyértelmü; a remélt szinergiák nem kellően valósulnak meg; a pólusok földrajzilag nem pontosan definiáltak (egy vagy több régió); a nemzetközi jelentőség követelménye nem teljesül, és a pénzügyi eszközök (1500 millió euró a 2006-2008-as időszakra) szétaprózódásának veszélye is fennáll. A pólusok finnanszírozásában a DATAR pénzügyi hozzájárulása elenyészö, ez a feladat a helyi közösségekre és más szervekre hárul (gyakran az állam-régió közötti szerzödések keretén belül).

A szerző a területfejlesztés több mint fél évszázadának vizsgálatából arra a következtetésre jut, hogy a területi harmonizáció az erőteljes gazdasági fellendülés időszakában (az olajválságot megelőző dicsőséges három évtizedben) válhatott teljesítendő céllá. A kiegyenlítỏ politika a hetvenes években bekövetkezett olajválsággal félbeszakadt. Eredménytelenségét mutatja a munkanélküliség növekedése, a társadalmi egyenlőtlenségek, a kirekesztés problémái. A válsággal a hatékonyság igénye lépett elötérbe; a nyolcvanas években a technopoliszok, majd a 2000-es években a versenyképességi pólus program céljai már nem esnek egybe a 1955-1975-ig tartó ipari decentralizációs politika területi harmonizációs célkitüzéseivel.

$\mathrm{Az}$ utolsó részben részletesen elénk tárja a szerző a 21 . századi sikeres francia területfejlesztési politika feltételeit, amelyek a folytonosság és a konszenzus a kitüzött célok és eszközök tekintetében. Franciaország számára követendő mintaként említi a holland példát. Hollandia a tenger elleni folyamatos küzdelem miatt a közvélemény által elfogadott, megértett és kívánt területfejlesztési politikát folytat év- 
századok óta, amely nem nélkülözi az eszközrendszer fejlödését (az 1961-ben létrejött nemzeti területfejlesztési tervek óta öt egymást követő terv született).

Elkerülhetetlen, hogy a konszenzuson alapuló területfejlesztési politika három, a társadalmat legsúlyosabban érintő legfóbb válságra keressen megoldást: az energiaválságra (mi lesz a kőolaj után), a klímaválságra (hogyan lehet csökkenteni az üvegházhatást okozó gázok kibocsátását), a társadalmi válságra (hogyan lehet reintegrálni a kirekesztetteket). Annak kulcsát, hogy a területfejlesztési politika ne csak üres szólam legyen, a szerző legfóképpen a globalizáció diktálta gazdasági érdekek (pénzügyek) primátusának visszaszoritásában, a területi és szociális kohéziós célok feléledésében, valamint a válságos helyzetú városrészek jelentős összegeket, energiát és összefogást igénylő rehabilitációjában látja. A társadalom által vallott elvek tekintetében a második világháború után létrejött konszenzus (világbéke, újjáépítés, gazdaságfejlesztés, társadalmi igazságosság, oktatás és egészségügy fejlesztése) felbomlott. A szerző szerint a három fő válságterület (energia, klíma és szociális) újbóli konszenzust tesz szükségessé annak érdekében, hogy a területfejlesztési politika minden szinten a valódi fenntartható fejlödés szolgálatába állhasson.

A történelmi áttekintés során végkövetkeztetésként Pierre Merlin arra hívja fel a figyelmet, hogy a bemutatott területfejlesztési politikák eredményei részlegesek és átmenetiek. Fő jellemzőik a kitüzött célok tekintetében a stabilitás hiánya, kivitelezésükben pedig a folytonosság hiánya. A tanulmány nagy értéke, hogy átfogó elemzést nyújt az ötvenes évektől napjainkig a területfejlesztés fó irányairól, külön fejezetet szentelve a vidékpolitika, a külvárosok, a tengerpart és a hegyvidék környezeti szempontokat és fejlesztést integráló sajátos problémáira. E didaktikus, szemléletes, a teljesség igényével íródott és konkrétumokban bővelkedő tanulmányt nagy haszonnal forgathatja az érdeklődők széles köre. 